\title{
Economics of Flower Cultivation with Special Reference to Orchid in Hilly Areas of West Bengal
}

\author{
Achyoung Lepcha, Shekhar D Khade* and Tuhin Roy
}

Department of Agriculture Economics, Uttar Banga Krishi Vishwavidyalaya, Pundibari, Coochbehar, West Bengal, India

*Corresponding author: shekharkhade4@gmail.com (ORCID ID: 0000-0002-9670-1658)

Received: $10-04-2020$

Revised: $15-07-2020$

Accepted: 29-08-2020

\begin{abstract}
The present study is an attempt to assess the cost of cultivation and economic viability of orchid cultivation in the hilly area of West Bengal with a unique set of primary data collected purposively during 201718 from the farm level. Based on farm size, farmers were categorised into three i.e. category-I $\left(500 \mathrm{ft}^{2}\right)$, category-II $\left(640 \mathrm{ft}^{2}\right)$ and category-III $\left(1000 \mathrm{ft}^{2}\right)$. Returns from different categories were found to increase with the time as Orchid usually shows significant boost in yield with time. The estimated costs of establishment of orchid farm for Category- I (500 sq. ft), Category- II (640 sq ft) and Category-III (1000 sq ft) were ₹ 67117.89, ₹ 69870.67 and ₹ 159746.51 respectively. The average net income in absolute term had been worked out to be ₹ 46,354.2, ₹ 34,143.2 and ₹ 1, 97,760 respectively. The values of financial feasibility analysis with Net Present Value (₹ 97,971.3), Benefit-Cost Ratio (1.76) and Internal Rate of Return $(25.38 \%)$ also proved that Orchid was a financially viable enterprise. Pay-back-period (3 to 5 years) was also reliable for investment though it varied little with size of farm. Keeping the commercial prospect of Orchid, it may be suggested for concerted efforts and more investment towards R\&D, infrastructure, extension for further development in this sector.

\section{Highlights}

(- Orchid cultivation was found to be a fairly profitable agribusiness enterprise in the area under study.
\end{abstract}

Keywords: Orchid, Pay-back-period, B-C Ratio, Net Present Value, Internal Rate of Return

Study on economic analysis of Orchid reinforces us to recognize that floriculture in general, and orchid in particular, is a lucrative profession in India. Orchids are the most beautiful flowers of God's creation and have conquered the cut flower industry all over the world during the last few decades. They are most pampered of all flowering plants, occupy top position among all flowering plants and are valued for cut flower production and as a potted plant (Singh, 2006). World floriculture industry is growing at a Compounded Annual Growth Rate (CAGR) of 10.74 per cent (Mohanan, 2016).

Government of India has identified floriculture as a sunrise industry and accorded it 100 per cent export-oriented status. Owing to steady increase in demand of flower, floriculture has become one of the important commercial trades in agriculture. The liberalization of industrial and trade policies paved the way for development of export-oriented production of cut flowers. It has been found that commercial floriculture has higher potential per unit area than most of the field crops and is, therefore, a lucrative business. Indian floriculture industry has been shifting from traditional flowers to cut flowers for export purposes. About 248.51 thousand hectares area was under cultivation in floriculture in 2014-15. Production of flowers is estimated to be 1,658 thousand tonnes loose flowers and 472

\footnotetext{
How to cite this article: Lepcha, A., Khade, S.D. and Roy, T. (2020) Economics of Flower Cultivation with Special Reference to Orchid in Hilly Areas of West Bengal. Economic Affairs, 65(3): 395-400.

Source of Support: None; Conflict of Interest: None (c) 9
} 
thousand tonnes cut flowers in 2014-15.The country has exported 22,086.10 MT of floriculture products to the world for the worth of ₹ 548.74 crores or 82.05 US\$ Millions in 2016-17(APEDA, 2017).

Table 1: Top five Production of cut flowers in India, (2017-18) (Production in '000 MT)

\begin{tabular}{lll}
\hline Sl. No. & State & Production (cut flower) \\
\hline 1 & West Bengal & 203.42 \\
2 & Madhya Pradesh & 97.91 \\
3 & Chhattisgarh & 79.91 \\
4 & Uttar Pradesh & 64.64 \\
5 & Karnataka & 62.31 \\
& India & $\mathbf{7 0 4 . 2 3}$ \\
\hline
\end{tabular}

In recent years, commercial production of orchid has come out as a profitable agribusiness option throughout the world, particularly in the developing countries. Orchid business has now become a lucrative profession of many people with much higher potential for returns compared to other agri-horticultural crops. India, especially North East and hill region is considered as a heritage of orchids and has a blooming future as far as orchid is concerned. The major advantages which offer a unique scope for judicious employment of existing resources and exploration of avenues yet untouched. (Chakrabarti, 2017).

In India Arunachal hills, Sikkim and Darjeeling hills with summer night and monsoonal summer are ideal for orchid (cymbidium) cultivation. The growth of orchid export from north - eastern hill region especially Sikkim would provide opportunities for employment and also development of supporting industries like packaging, cold storage and transportation (NRCO, 2011).

Orchids are also found to grow commercially in different hilly areas of West Bengal for its favourable agro-climatic situation. References show that orchids can afford good return over cost. Mainly, small and marginal farmers are attached with this sector. Women labours are also involved in orchid cultivation. Orchids can be a good alternative source of farm income if it is undertaken with modern package of practices.

Thus, considering the social and economic importance of production and marketing of orchids, an attempt has been made in this exercise to study orchid cultivation, cost, marketing, returns, etc with an aim of generating information for a specific agro-climatic zone (usually hilly zones of West Bengal) for future reference. Accordingly, the study will cover specific objectives of analyzing investment pattern, profitability and constraints and suggestions

\section{MATERIALS AND METHODS}

Technique of sampling was followed purposively. The numbers of orchid cultivators in the district were very small. Thus, majority of them was considered for the study. About 40 orchids growing farmers were identified, contacted and surveyed personally for obtaining detailed information. A structured schedule was framed up for collection of relevant data/information. Farmers were categorised into three i.e. Category-I (500 $\left.\mathrm{ft}^{2}\right)$, Category-II (640 $\left.\mathrm{ft}^{2}\right)$ and Category-III (1000 $\left.\mathrm{ft}^{2}\right)$. Data, thus, obtained were compiled and put on excel sheet for calculation and thereafter interpretation as per the requirement of the objectives.

Discounted cash flow techniques were used to find out the economic viability of investment in orchid cultivation. Cash flow stream was discounted at 12 per cent interest rate.

$$
\text { Pay-back Period }=\frac{\text { Investment }}{\text { Annual cash flow }}
$$

Benefit Cost Ratio: A ratio above one indicates that the project is viable.

$$
\mathrm{BCR}=\sum \frac{B n}{(1+r)^{n}} / \sum \frac{C n}{(1+r)^{n}}
$$

$B n=$ Benefit cost, $C n=\operatorname{cost} r=$ Discount rate, $n=$ time of the cash flow

Net Present Value: A project having positive net present worth is considered as viable.

$$
\text { Net Present Value }=\sum \frac{B n}{(1+r)^{n}}-\sum \frac{C n}{(1+r)^{n}}
$$

where

$B n=$ Benefit cost, $C n=$ cost $r=$ Discount rate, $n=$ time of the cash flow

Internal Rate of Return (IRR): It is the power or capacity of the investment which shows the rate of return of the investment which is internally 
produced. It is estimated at the interest rate where NPV becomes zero.

$$
\mathrm{IRR}=\sum \frac{B n}{(1+r)^{n}}-\sum \frac{C n}{(1+r)^{n}}
$$

Where,

$B n=$ Benefit cost, $C n=$ cost, $r=$ Discount rate, $n=$ time of the cash flow

\section{Total Cost of Production}

Cost of cultivation included variable costs (VC) and fixed costs (FC).

Fixed costs comprised of apportioned cost of establishment, which was used in the orchid production, comes under the fixed cost. Apportioned cost was estimated by dividing the total fixed cost by no. of year of economic yield of orchid crop.

Thus, Total cost of production $=$ Apportioned fixed costs + Variable cost

Variable costs $=$ labour cost + material cost has remained same in four to nine seven years age group of plants.

\section{Other related concepts are as follows:}

(i) Gestation period: It is period for which time taken up to bearing after establishment of orchid garden. In the study areas, it was 3 year (approx...)

(ii) Bearing period: It is time of flowering which includes economic life period i.e., up to 8 years in orchids.

(iii) Payback period: It is the period (no. of years) required to recover the initial investment with incremental return.

(iv) Gross income: It is the value of total quantity of orchid produced at the prices where the product is sold.

(v) Net returns: Gross returns - Total cost.

(vi) Unit cost: Since the land holdings of the orchid growers are small, and initial investment per square feet is high, the costs are calculated on the basis of per square feet as unit cost.

\section{Garrett's Ranking Technique}

As per this method, respondents have been asked to assign the rank for all factors and the outcomes of such ranking have been converted into score value with the help of the following formula:

$$
\text { Percent position }=100(R i j-0.5) / N j
$$

Where $R i j=$ Rank given for the $i^{\text {th }}$ variable by $j^{\text {th }}$ respondents $N j=$ Number of variable ranked by $j^{\text {th }}$

\section{RESULTS AND DISCUSSION}

\section{Investment pattern in orchid production}

In orchid cultivation the investment was made in establishing the green house for orchids. The costs incurred in the green house up to bearing stage which takes three years, formed the establishment cost of the green house for orchid cultivation

\begin{tabular}{|c|c|c|c|c|}
\hline \multirow[b]{2}{*}{$\begin{array}{l}\text { Sl. } \\
\text { No. }\end{array}$} & \multirow[b]{2}{*}{ Particulars } & \multicolumn{3}{|c|}{ Category- Category- Category- } \\
\hline & & $\begin{array}{l}\text { I } \\
(n=7)\end{array}$ & $\begin{array}{l}\text { II } \\
(\mathrm{n}=14)\end{array}$ & $\begin{array}{l}\text { III } \\
(n=19)\end{array}$ \\
\hline A. & Investment costs & $\begin{array}{l}\text { Value } \\
\text { in ₹ }\end{array}$ & $\begin{array}{l}\text { Value } \\
\text { in ₹ }\end{array}$ & $\begin{array}{l}\text { Value } \\
\text { in ₹ }\end{array}$ \\
\hline 1 & $\begin{array}{l}\text { Greenhouse } \\
\text { (including shade net, } \\
\text { UV sheet, labour for } \\
\text { construction) }\end{array}$ & 53,000 & 55,000 & $1,41421.05$ \\
\hline 2 & Water Tank & 4214.28 & 4607.14 & 6842.10 \\
\hline 3 & Sprayers & 1642.85 & 1692.85 & 1800 \\
\hline 4 & $\begin{array}{l}\text { Baskets and trolley, } \\
\text { Agricultural Sickle }\end{array}$ & 271.42 & 282.14 & 286.84 \\
\hline 5 & $\begin{array}{l}\text { Planting materials } \\
\text { (including plant and } \\
\text { pot) }\end{array}$ & 1671.42 & 1707.14 & 1810.52 \\
\hline & TOTAL & 60799.97 & 63289.27 & 152160.51 \\
\hline \multirow[t]{3}{*}{ B. } & Maintenance cost & 6317.92 & 6581.4 & 7286 \\
\hline & $\begin{array}{l}\text { Total establishment } \\
\text { cost }\end{array}$ & 67117.89 & 69870.67 & 159746.51 \\
\hline & $\begin{array}{l}\text { Total establishment } \\
\text { cost/ } 10 \text { years * }\end{array}$ & 6711.78 & 6987.06 & 15974.65 \\
\hline
\end{tabular}

Table 2: Investment pattern in orchid cultivation

* Assume 10 years.

The results related to cost of establishment of green house for orchid cultivation on per unit area i.e. 500, 640, 1000 (sqft) are presented in Table 1. The total cost of establishment per area is ₹ 67117.89, $₹ 69870.67$ and $₹ 159746.51$ for 500,640 and 1000 (sqft) respectively. The investment cost constituted the major share of the total establishment cost. Out of the total per area investment cost, the establishment cost was ₹ 61580, ₹ 63800 and ₹ 209070 for 500, 640 
and 1000 (sq.ft) and maintenance cost was ₹ 6711.78, ₹ 6987.06 and ₹15974.65 for 500, 640 and 1000 (sq.ft).

\section{Cost and returns from orchids in different age group gardens during bearing period.}

\section{The cost and returns structure of category I}

From the chart below it is seen that with the increase in the age of the garden the total cost of production went on increasing i.e. ₹ 11,863.15 during third year to ₹ $12,524.77$ during fourth year to ₹ $13,684.51$ during fifth year. Orchid plants start yielding flowers from third year onwards at 200 spikes per area to 250 spikes to 350 spikes as the age of the plant advances. The selling price at the producer level is based on per spike.

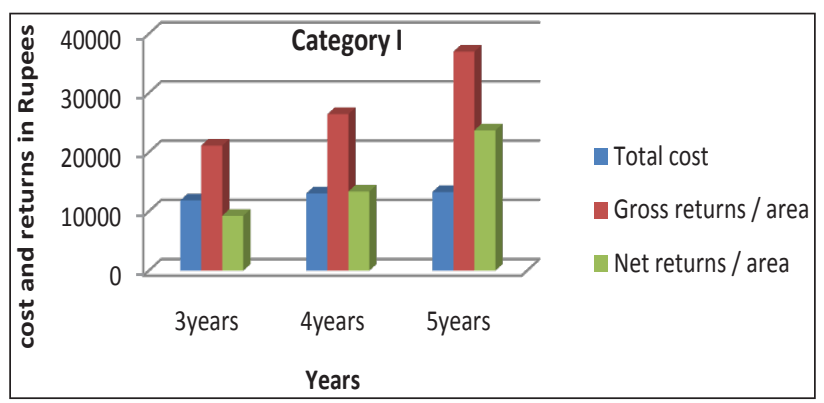

Fig. 1: Cost and Returns from Orchids for Category-I

In third year the gross returns worked out to be ₹ 21,142.8 per area, which increased with the age of the gardens to ₹ $26,428.5$ in the fourth year to ₹ 36,999.9 during five years. Net return generated from $500 \mathrm{sq} \mathrm{ft}$ of orchid production was ₹ 9279.65 during third year same was increased to ₹ $13,369.06$ during fourth year to ₹ 23708.72 during fifth year age group of gardens.

\section{Cost and Returns from Orchids for Category-II}

Similarly the total cost of production went on increasing with the age of the garden, i.e. ₹ 12,524.77 during third year to ₹ $13,684.51$ during fourth year. Orchids start yielding flowers from third year onwards at 300 spikes per area to 350 spikes as the age of the plant advances. The selling price at the producer level is based on per spike. On an average ₹ 92.85 was obtained by the producers for each spike grown.

The gross returns worked out to be ₹ 27,855 per area in third year which increased with the age of the gardens to ₹ 32,497 in the fourth year. Net return generated from 640 sqft of orchid production was ₹ 15330.23 during third year same was increased to ₹18812.99 during fourth year age group of gardens as shown in the Fig. 2 below.

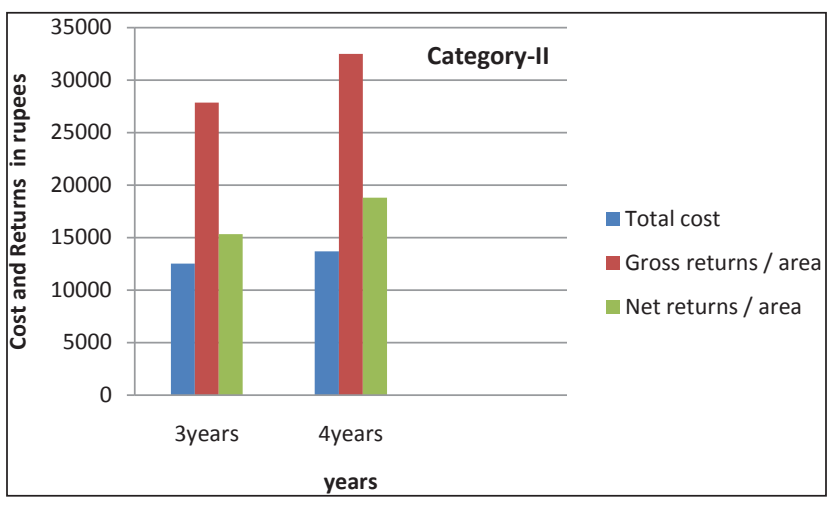

Fig. 2: Cost and Returns from Orchids for Category-II

\section{Cost and Returns from Orchids Category-III}

For category III (1000 sqft), cost of production here also went on increasing with the age of the garden, i.e. ₹ 24,530.39during third year to ₹ 25003.34 during fourth year to ₹ 25375.99 during fifth year to ₹ 25,611.08 during sixth year to ₹ 25124.19 during seventh year. Orchid plants start yielding flowers from third year onwards at 500 spikes per area to 650 to 800 to 1000 spikes as the age of the plant advances. The selling price at the producer level is based on per spike. On an average ₹ 92.63 was obtained by the producers for each spike grown.

The gross returns worked out to be ₹ 46,315 per area in third year which increased with the age of the gardens to ₹ 50,946.5 in the fourth year to ₹ $60,209.5$ during fifth year to ₹ 74,104 during sixth year to ₹92630 during seventh year. Net return generated from 1000 sqft of orchid production was ₹ 21,784.61 during third year same was increased to ₹ 25,943.16 during fourth year to ₹ 34,833.51 during fifth year to ₹ 48,492.92 during sixth year to ₹ 66705.81 during seventh year age group of gardens (Fig 3).

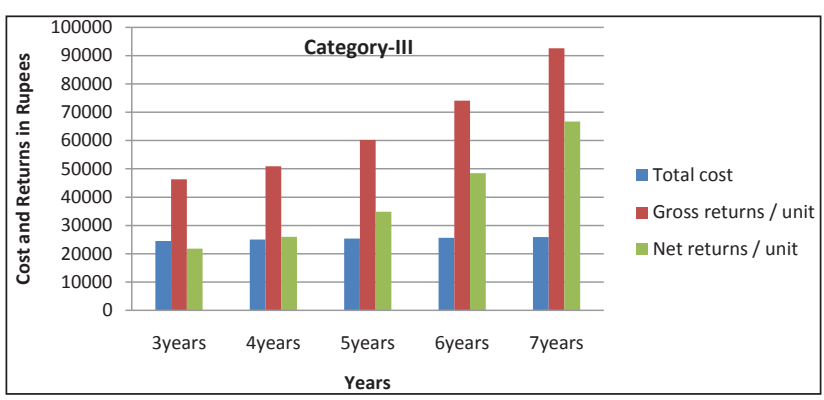

Fig. 3: Cost and Returns from Orchids for Category-III 
Table 3: Estimation of Discounted Benefit -Cost Ratio (BCR)

\begin{tabular}{lllllll}
\hline Year & $\begin{array}{l}\text { Discounting } \\
\text { Factor @7\% }\end{array}$ & Total Cost & $\begin{array}{l}\text { Discounted } \\
\text { Total cost }\end{array}$ & Benefit & $\begin{array}{l}\text { Discounted } \\
\text { benefit }\end{array}$ & $\begin{array}{l}\text { Benefit - Cost } \\
\text { Ratio }\end{array}$ \\
\hline $1^{\text {st }}$ & 0.9346 & 23260.65 & 21739.40 & & & \\
$2^{\text {nd }}$ & 0.8734 & 18947.14 & 16548.43 & & & \\
$3^{\text {rd }}$ & 0.8163 & 24530.39 & 20024.15 & 46315 & 37806.93 & \\
$4^{\text {th }}$ & 0.7629 & 25003.34 & 19075.54 & 50946.5 & 38867.08 & 1.76 \\
$5^{\text {th }}$ & 0.7130 & 25375.99 & 18093.08 & 60209.5 & 42929.37 & \\
$6^{\text {th }}$ & 0.6663 & 25611.08 & 17064.66 & 74104 & 49375.49 & \\
$7^{\text {th }}$ & 0.6227 & 25924.19 & 16142.99 & 92630 & 57680.70 & \\
\hline Total & & 128688.3 & & 226659.6 & \\
\hline
\end{tabular}

\section{Financial Analysis of Investment in Orchid Cultivation (Project Appraisal Technique)}

Orchid is a perennial crop. Once it is established, it gives economic return for several years over cost. Estimation in absolute term for a business like Orchid with stream of returns and costs is quite complex and cannot explain the overall economic viability. Accordingly, the discounted technique of project appraisal has been done as a part of financial analysis of investment to study the economic viability or feasibility of Orchid cultivation. The techniques followed in this exercise are as follows:

(I) Benefit Cost Ratio (BCR)

(II) Net Present Value (NPV)

(III) Internal Rate of Return (IRR)

Before going for estimation through the discounted techniques, it was presumed that all other external economic variables like inflation, market cost \& price, subsidy, incentives, etc. would remain constant since they have equal influence on both costs and prices and may not have any deviation from the original impact.

\section{(I) Benefit Cost Ratio (BCR)}

A benefit-cost ratio (BCR) is an indicator, used in benefit-cost analysis that attempt to summarize the overall value for money of a project or proposal. The benefit-cost ratio analysis done for the CategoryIII (with farm size $1000 \mathrm{sqft}$ ) only because it provides income flows for about seven years. Data from this category can only be applied for this analysis. Information from other two categories of farm was not adequate to pursue this analysis. Institutional agencies are giving loan to this sector with an interest rate of 7 per cent per year. As such, discounting of both cost and return was done at the level of 7 per cent. Return from Orchid flower was considered as benefit and cost of production was treated as cost. Findings of the benefit-cost analysis have been shown in Table 3 .

The estimated value of benefit-cost ratio is 1.76 . This implies that Orchid is a profitable business and it is also a viable enterprise. Farmers may invest more in bigger size of Orchid garden to have more financial advantages in future.

\section{(II) Net Present Value (NPV)}

Net present value (NPV) of an investment is the difference between the discounted present value of series of inflow (returns) and outflows (costs) over the economic life period of the orchid plants. The Net present value (NPV) has been calculated at ₹ 97,971.3 which re-confirms the financially viability of the Orchid crop.

\section{(III) Internal Rate of Return (IRR)}

Internal rate of return (IRR) is the interest rate at which the net present value of all the cash flows (both positive and negative) from a project or investment equals zero. The IRR calculated for orchid cultivation in the study area was found to be 25.389per cent, indicating that the investment in orchid house was profitable, considering the present bank rate of interest $(7 \%)$.

To sum up, the findings with remark of financial analysis have been presented below:

\begin{tabular}{lll}
\hline Technique & Value & Remarks \\
\hline $\begin{array}{l}\text { Benefit Cost Ratio } \\
(\mathrm{BCR})\end{array}$ & 1.76 & $\begin{array}{l}\text { Orchid Cultivation is } \\
\text { financially Viable. }\end{array}$ \\
$\begin{array}{l}\text { Net Present Value } \\
(\mathrm{NPV})(₹)\end{array}$ & 97971.5 & \\
$\begin{array}{l}\text { Internal Rate of } \\
\text { Return (IRR) }(\%)\end{array}$ & 25.389 & \\
\hline
\end{tabular}




\section{Constraints of Orchid Production}

Analysis of constraints associated with production of orchid through Garrett Ranking is shown in the Fig 4. Among nine factors considered, the lack of technical guidance was the major problem as expressed by most of the farmers and is given the I $^{\text {st }}$ rank. This is followed by high cost of maintenance (II rank), non-availability of pesticides and insecticides (III rank), high rate of plant protection measures (IV rank), Lack of credit facility (V rank), high cost of planting material (VI rank), high incidence of pest and diseases (VII rank), high wage rate (VIII rank) and non- availability of skilled labour (IX rank).

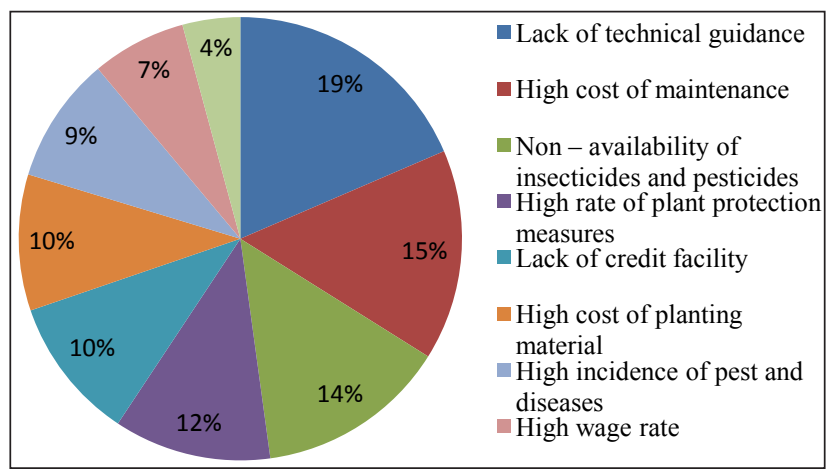

Fig. 4: Problems in Orchid Production

\section{Suggestions and Policy implications}

Analysis reveals that though economically viable, Orchid cultivation still lacks of awareness for application of modern technology which is followed by other services and infrastructural facilities. Since, the crop is commercially highly demanded and is mainly undertaken by the resource-poor farmers, appropriate strategies or policies for holistic development in this regards may be adopted by the Govt. or different institutional agencies as well as private entrepreneurs.

\section{CONCLUSION}

The study shows that the costs of establishment of Orchid farm were ₹ 67117.89, ₹ 69870.67 and $₹ 159746.51$ and average net income in absolute term had been worked out to be ₹ 46,354.2, ₹ 34,143.2 and ₹ 1, 97,760 for category-I, II and III respectively with its economic life span of five to six years. The BCRs were found to be greater than one, NPVs were positive and IRRs were greater than opportunity cost of capital. Cultivation of this crop lacks awareness about modern technologies as well as facilities of infrastructural and other services which calls for institutional as well as private sector initiatives. However, Orchid cultivation was found to be a fairly profitable agribusiness enterprise in the area under study.

\section{REFERENCES}

Aiswarya Mohanan. 2016. "Economic analysis of orchid cultivation in Kerala", International Journal of Current Research, 8(10): 40366-40368.

Borude, S.G. and Talathi, J.M. 1991. Organisation and flower marketing system of Bombay flower market. Baliraja, pp. 158-160.

Chakrabati. 2017. Orchids - the lucrative floricultural crop for Entrepreneur Development and Employment generation, National Conference on Advances in Indian Floriculture with Focus on North-East \& Hill Region, Poster No. 04.

De. 2011. Value addition in flowers and orchids, Vikas Surya Plaza, CU Block, L.S.C Market, Pritam Pura, New Delhi, ISBN 978-93-81450-12-3.

Kumar, G.S. Rawat and Wood. 2011. Diversity and Ecology of Dendrobiums (Orchidaceae) in Chotanagpur Plateau, India. Taiwania, 56(1): 23-36.

Medhi, R.P. and Chakrabarti, S. 2009. Traditional Knowledge of NE people on conservation of wild orchids. Indian Journal of Traditional Knowledge, 8(1): 11-16.

Vidya, D. 2006. Potential of cut flower production in India, Financing agriculture - A National Journal of Agriculture and Rural Development, 6: 22-24. 